\title{
Patterns of Fish Assemblage, Growth, and Diet Composition in a Tropical River between Two Cascading Hydropower Dams
}

\author{
Lee Nyanti $\mathbb{D}^{1},{ }^{1}$ Chen-Lin Soo ${ }^{(D)},{ }^{2}$ Afina-Yian Chundi $\left(\mathbb{D},{ }^{3}\right.$ Elsa-Cordelia-Durie Lambat $\left(\mathbb{D},{ }^{3}\right.$ \\ Alvinna Tram $\mathbb{D},{ }^{3}$ Teck-Yee Ling $\mathbb{D}^{3},{ }^{3}$ Siong-Fong Sim $\mathbb{D}^{3},{ }^{3}$ Jongkar Grinang $\mathbb{D},{ }^{3}$ \\ Tonny Ganyai $\left(\mathbb{\infty},{ }^{1}\right.$ and Karen-Suan-Ping Lee $\mathbb{1}^{1}$ \\ ${ }^{1}$ Research and Development Department, Sarawak Energy Berhad, Kuching 93050, Sarawak, Malaysia \\ ${ }^{2}$ Institute for Tropical Biology and Conservation, Universiti Malaysia Sabah, Jalan UMS, Kota Kinabalu 88400, Sabah, Malaysia \\ ${ }^{3}$ Faculty of Resource Science and Technology, Universiti Malaysia Sarawak, Kota Samarahan 94300, Sarawak, Malaysia \\ Correspondence should be addressed to Chen-Lin Soo; qianlin1112@gmail.com
}

Received 11 December 2020; Revised 27 January 2021; Accepted 1 February 2021; Published 18 February 2021

Academic Editor: Agoes Soegianto

Copyright (c) 2021 Lee Nyanti et al. This is an open access article distributed under the Creative Commons Attribution License, which permits unrestricted use, distribution, and reproduction in any medium, provided the original work is properly cited.

Construction of cascade dams has been shown to have impacts on fish assemblages and biodiversity. Yet, there is no literature on fish assemblages in the Murum River that connects the cascading Bakun and Murum dams in Sarawak, Malaysia. Hence, study on this modified ecosystem is necessitated to better understand the effects of the cascade dam construction on fish fauna. For this, fish samples were caught at five stations located along the river during both dry and wet seasons. Environmental parameters were taken concurrently with fish sampling. Length-weight relationship, condition factors, and diet composition of selected fish species in the river were also determined. The present study demonstrated that there are indications of the impact of cascading dams on the formation of a complex ecosystem in the Murum River, that is, changing from the shallow downstream of the Murum Dam to the deep transitional and inundated zone of the Bakun reservoir. The transitional zone in the Murum River exhibited the lowest fish species diversity, richness, and evenness during the dry season due to low $\mathrm{pH}$ and DO coupled with high turbidity. The biological indices improved when the water quality improved during the wet season. On the contrary, the diversity and evenness indices at the inundated tributary station decreased remarkably during the wet season, likely due to the migration of fish during the onset of the rainy season. This study showed that Barbonymus schwanenfeldii has a wider feeding habit which contributes to its higher distribution and abundance in the Murum River. The growth patterns of B. schwanenfeldii, Cyclocheilichthys apogon, Hampala macrolepidota, Lobocheilos ovalis, and Osteochilus enneaporos were better during wet than dry season. Overall, the condition factor of all native fish species in the Murum River was in poor to fair condition, whereas the exotic species, Oreochromis mossambicus, exhibited excellent condition $(K$ value $>2$ ) for both seasons. The increase in the number of $O$. mossambicus coupled with its high condition factor indicates biological intrusion and a potential threat to the native fish species in the Murum River. Continuous monitoring is essential to detect in-time risk issues associated with environmental degradation and biological invasion in this regulated and inundated river ecosystem.

\section{Introduction}

Physical structures such as dams and reservoirs were made to fulfil man's needs for the purposes of power generation, flood control, recreation, agriculture, and industry. Dam impoundment inevitably modifies the natural regime of its downstream rivers and has resulted in environmental degradation [1-3]. The fluctuations of flow and environmental conditions could lead to alteration of aquatic biodiversity in the downstream river [4]. Nyanti [5] demonstrated that the downstream river of the tropical Batang Ai Dam is extremely shallow and slow flowing when the power generation is halted, and no water is discharged from the powerhouse, which has subsequently reduced the fish abundance in the river. In addition, seasonal changes in the hydrology of the downstream river could also lead to differences in fish assemblages [6]. 
Studies have been conducted on the impacts of cascade dam construction since the implementation of the extensive cascade hydropower plant $[7,8]$. The construction of cascade dams in a river caused a repeated segment of the river being divided into a series of inundated areas. The effects of cascading dams on the environment are more complex than the effects of a single dam due to the cumulative effects of the cascading dams [7]. Xie et al. [9] demonstrated that the development of cascade hydropower and continued dam construction had exerted a major influence on the fish species composition, where the endemic headwater species had declined in the upper reaches of the Yellow River, China, due to habitat alteration.

In Sarawak, two large hydroelectric dams, namely, the Murum hydroelectric dam and the Bakun hydroelectric dam, are both located upstream of the Rajang River. The Murum hydroelectric dam with a catchment area of $2750 \mathrm{~km}^{2}$ is located on the Murum River, a tributary of the uppermost part of the Rajang River. Less than $100 \mathrm{~km}$ downstream is the Bakun hydroelectric dam with a catchment area of $14,750 \mathrm{~km}^{2}$ located on the Rajang River [10]. These cascading hydroelectric dams are connected by a segment of the Murum River which possesses a complex ecosystem as it is not only influenced by the regulated flow from the Murum Dam but also by the transitional zone and inundated area of the Bakun reservoir.

To date, no study has been conducted on the fish assemblages along the Murum River between the two cascade dams after their impoundment. As more hydroelectric dams are planned to be constructed in the region [10], a study on the effects of the cascade dam construction on this tropical ecosystem is warranted. Therefore, this study aimed to investigate the patterns of fish assemblages in the Murum River that connects the two dams during the dry and wet seasons. In addition, the growth pattern and diet composition of selected fish species in the Murum River were also studied.

\section{Materials and Methods}

2.1. Field Collection and Laboratory Analysis. Two sampling trips were made in July and October 2016 during the dry and wet seasons, respectively. Both samplings were conducted at five stations along the Murum River located between Murum hydroelectric dam and the Bakun hydroelectric dam, as shown in Figure 1. The sampling station was determined according to the zonation commonly occurring in the reservoir along the downstream gradient. Station 1 and station 2 were located at the downstream of the Murum Dam which is part of the riverine zone of the Bakun hydroelectric reservoir. The Murum Hydroelectric Powerhouse was located in between the two stations. Station 3 was located at the transitional zone of the Bakun hydroelectric reservoir, whereas station 5 was located at the inundated area of the Bakun Dam. Lastly, station 4 was located at the Temaju River, a tributary of the Murum River.

Gill nets of various mesh sizes $(2.54 \mathrm{~cm}, 5.08 \mathrm{~cm}$, $6.35 \mathrm{~cm}$, and $7.62 \mathrm{~cm}$ ) and three-layered gill nets $(14 \mathrm{~cm}-$ $4 \mathrm{~cm}-14 \mathrm{~cm}$ ) were used for fish sampling at each station for a duration of three days and two nights. During this period, the nets were left overnight and retrieved on the next day. Fish were counted and grouped according to their respective species in the field. Taxonomy keys $[11,12]$ were used for fish species identification. The taxonomic status was also confirmed with the latest literature [13-15] and online global database of fish species $[16,17]$. Fish that cannot be identified in the field were preserved by using $10 \%$ formalin for approximately 72 hours followed by preservation in $70 \%$ ethanol. The total length $(L)$ and body weight $(W)$ of fishes were recorded by using a ruler and a portable balance (Shimadzu, ELB200) to the nearest $0.1 \mathrm{~cm}$ and $0.01 \mathrm{~g}$, respectively. Environmental parameters were taken concurrently with the fish sampling. Water depth was measured at each station using a depth finder (Speedtech Instruments 67505). In situ water quality parameters including dissolved oxygen (DO), temperature, $\mathrm{pH}$, turbidity, and conductivity were taken by using YSI Multiparameter Water Quality Sonde (YSI 6920). Triplicate measurements were taken from subsurface $(0.5 \mathrm{~m})$ and bottom ( 3 to $5 \mathrm{~m}$ ) water columns. The data were then pooled for subsequent analysis at each station.

The top four abundant fish species from the family Cyprinidae were selected for stomach content analysis. The samples were analysed by pooling the data from the two trips due to the limited number of samples. Each individual was dissected to obtain its stomach by using a dissecting kit (Gold Cross) and was fixed in 5\% formalin for further analysis. For the stomach content analysis, the fish stomach was cut longitudinally, and the stomach content was sorted according to the food type under a stereomicroscope (Olympus SZ51) and weighed to the nearest $0.001 \mathrm{~g}$ by using a balance (Shimadzu BL-220H).

2.2. Data and Statistical Analysis. Shannon-Weiner's diversity index $(H)$ [18], Pielou's evenness index $(J)$ [19], and Margalef's species richness index (D) [20] were used to determine the species diversity, richness, and evenness indices at each station and the whole study area. The biological indices were calculated using formulae (1)-(3).

Shannon-Weiner's diversity index $(H)$ :

$$
H=\sum \frac{N_{i}}{N} \log e \frac{N_{i}}{N} \text {. }
$$

Pielou's evenness index $(J)$ :

$$
J=\frac{H}{\log e S} .
$$

Margalef's index of species richness $(D)$ :

$$
D=\frac{S-1}{\log e N},
$$

where $N=$ sample size, $N_{i}=$ number of specimens per species, and $S=$ total number of species.

The stomach content of fish was analysed by using the frequency of occurrence (FO) and mass method (MM) [21]. The FO was used to calculate how frequently the food type occurs in each individual using 


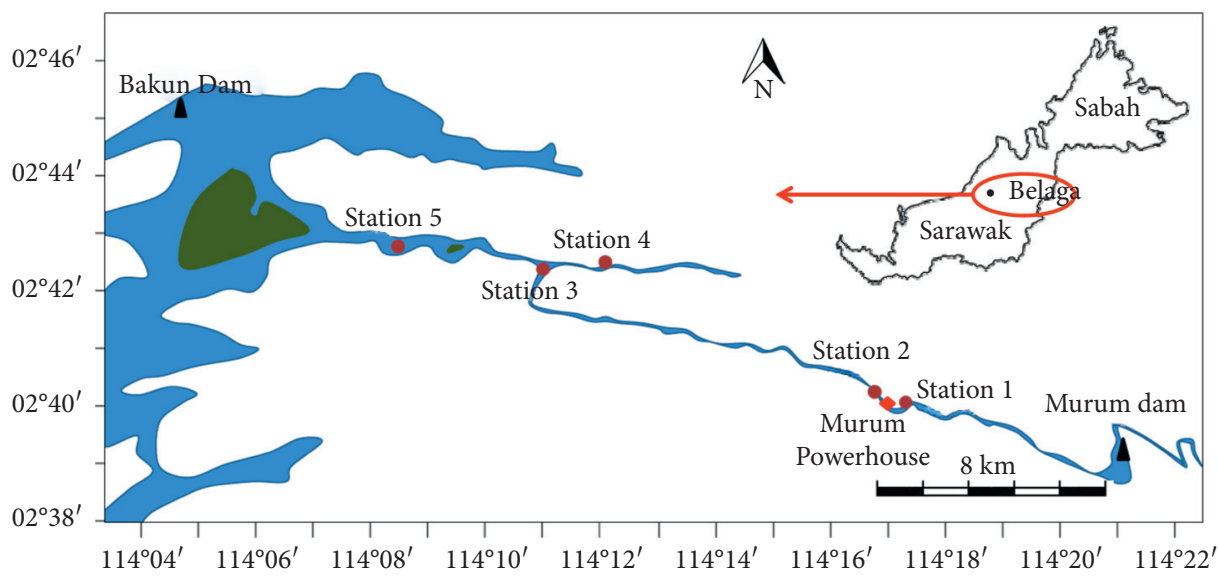

FIgURE 1: The location of sampling stations at the study area.

$$
\% \mathrm{FO}_{i}=\frac{N_{i}}{N} \times 100,
$$

where $\mathrm{FO}_{i}=$ frequency of occurrence of food item $i, N_{i}=$ the number of stomachs in which the given item $i$ occurs, and $N=$ the total number of stomachs examined with food.

The MM was used to determine the diet composition of the species by using

$$
\% \mathrm{MM}_{i}=\frac{m_{i}}{m_{t}} \times 100,
$$

where $\% \mathrm{MM}_{i}=$ the mass percentage of food item $i, m_{i}=$ the mass of food item $i$, and $m_{t}=$ the total mass of food (gut content).

Length-weight relationship (LWR) [22] of selected fish species was expressed using

$$
W=a L^{b} .
$$

The constants $a$ and $b$ were estimated using linear regression as

$$
\log W=\log a+b \log L
$$

where $W$ is the weight of the fish (g), $L$ is the length of the fish $(\mathrm{cm}), \log a$ is the intercept, and $b$ is the regression coefficient. The growth of the fish was indicated by the $b$ value, where $b=3$ indicates an isometric growth rate, $b>3$ is a positive allometric growth, and $b<3$ is a negative allometric growth.

Finally, the condition of the selected fish species was determined by using Fulton's condition factor $(K)$ [23]:

$$
K=100 \mathrm{~W} / \mathrm{L}^{3} \text {. }
$$

One-way ANOVA followed by Tukey post hoc test was used to determine the significant difference of each water quality parameter among stations at each trip, while independent-sample $T$-test was used to determine if there is a significant difference between trips at each station. Pearson's correlation analysis was performed to elucidate the significant relationships between biological indices and water quality parameters. All statistical analyses were significant at $p \leq 0.05$ carried out using the Statistical
Package for Social Sciences (SPSS version 24, SPSS Inc., 1995).

\section{Results and Discussion}

3.1. Fish Composition in the Murum River during Dry and Wet Seasons. Figure 2 shows that a total of four and seven families were caught during the first trip (dry season) and the second trip (wet season) in the Murum River, respectively. A total of 360 individuals comprising of 18 species were caught during the dry season, while 267 individuals from 20 species were collected during the wet season. The family Cyprinidae dominated the Murum River in both seasons, constituting $88.6 \%$ (319 individuals) and $83.1 \%$ (222 individuals) of the total catch during the dry and wet seasons, respectively. This is similar to a previous study in the two tributaries of the Murum River located upstream of the Murum Dam reservoir, where it was reported that Cyprinidae was the most dominant family (62.1\%) [24]. Nyanti [5] also demonstrated that the most dominant family in the downstream river of the Batang Ai Dam was Cyprinidae (67.9\%). The dominance of cyprinids is shown throughout the Southeast Asian region [25-27]. Numerous studies have also reviewed that cyprinids are the most common freshwater fish family in Malaysia [28, 29]. Beamish et al. [25] explained that cyprinids are dominant compared to other fish families as they are able to inhabit a broad range of environments due to their adaptive stomach, genetic modification, and intestine adaptation efforts.

During the dry season, the second dominant family caught was Bagridae (7.8\%), followed by Cichlidae (3.1\%) and Siluridae $(0.6 \%)$. During the wet season, Cichlidae was recorded as the second dominant family $(10.1 \%)$, followed by Bagridae (4.9\%) and Siluridae (0.7\%). Meanwhile, Cobitidae, Mastacembelidae, and Pangasiidae were the least dominant families where only one individual was caught for each family. According to Sapis et al. [24], the presence of introduced species, specifically cichlids in the Murum River, may be due to the accidental release of cultured fish from community ponds during the dam impoundment. The present study demonstrated that cichlids have overtaken the bagrids during the wet season because they are hardier and 


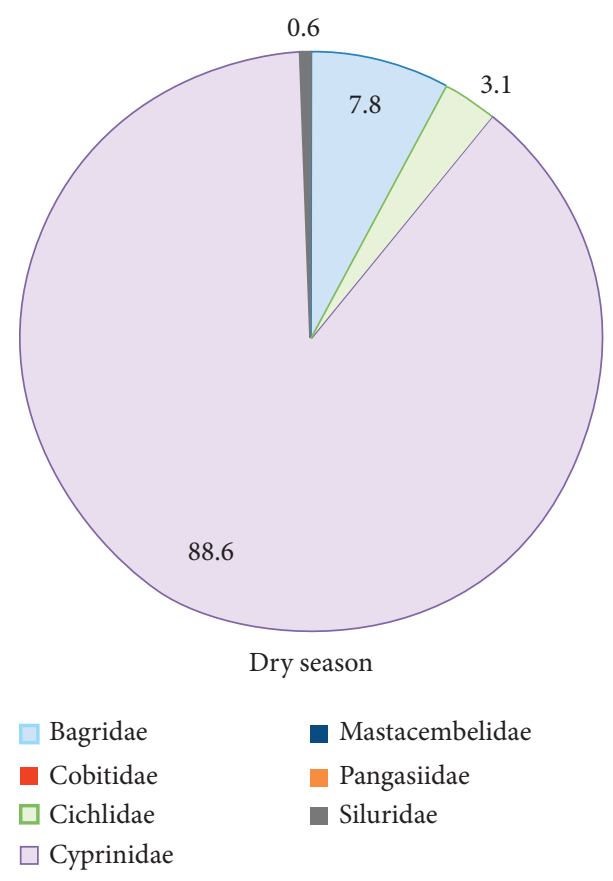

(a)

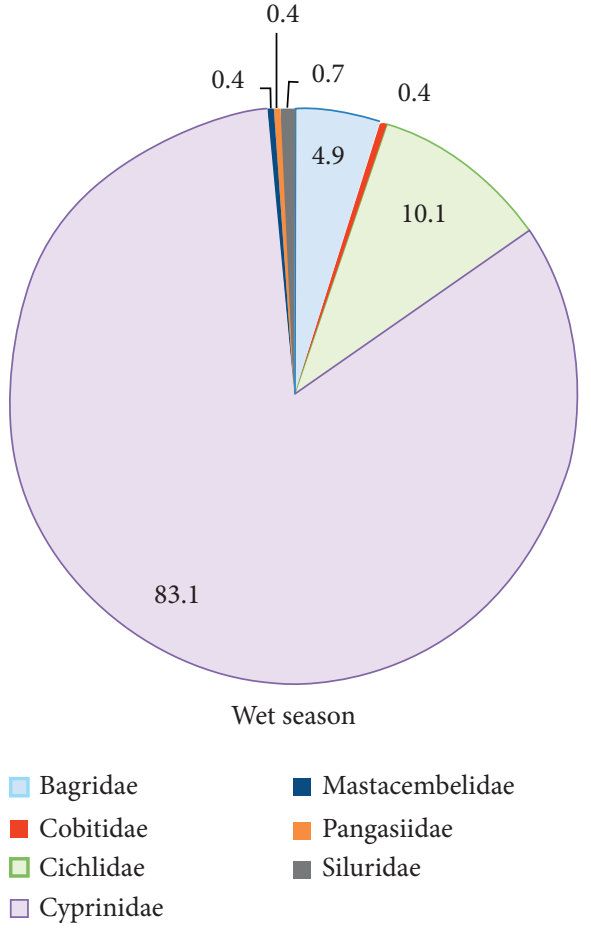

(b)

Figure 2: The overall percentage of the fish family recorded in the study area.

more tolerant to a wide range of environmental conditions than the Malaysian native species [30-32]. The increase of cichlid abundance in the Murum River over time might be an early warning sign of biological invasion, which could pose a serious threat to the native species in the river as well as the functioning of the ecosystem [33].

Table 1 shows the list of fish composition at each station in the Murum River during the dry and wet seasons. Barbonymus schwanenfeldii $(n=76)$ and Cyclocheilichthys apogon $(n=76)$ were the most abundant species in the Murum River during the dry season, followed by Osteochilus hasseltii $(n=54)$ and Parachela oxygastroides $(n=34)$. During the wet season, $B$. schwanenfeldii $(n=118)$ was recorded as the most abundant species, followed by C. apogon $(n=29)$ and $P$. oxygastroides $(n=29)$. The dominance of $B$. schwanenfeldii in the present study differed with the fish assemblages at the downstream river of the Batang Ai Dam where fish species were low in abundance $(\approx 1.4 \%)$, although both rivers downstream of the dam were abundant in C. apogon [5]. This could be due to the complex ecosystem of the Murum River that is changing from the shallow downstream of the Murum Dam to the deep transitional and inundated zone of the Bakun reservoir, which favours $B$. schwanenfeldii as it moves into inundated areas during the wet season to feed and spawn [34]. This is also in agreement with the present result whereby the abundance of $B$. schwanenfeldii was higher during the wet season than that during the dry season, particularly at the inundated area (station 4). On the contrary, the abundance of C. apogon was lower during the wet season than the dry season, while $O$. hasseltii was not found in the river during the wet season. The lower abundance or complete absence of fish species during the wet season could be due to the migration behaviour of the fish [34] or the removal of fish species due to the modification of habitat in the river [4]. The variations in abundance and occurrence of fish species indicates that restructuring of fish communities in this river is still ongoing as the river is just recently been modified. Therefore, continuous and long-term monitoring is necessary for a better understanding of fish composition and distribution patterns in the regulated river.

Table 2 shows the fish biological indices in the Murum River and at each station during the dry and wet seasons. Overall, the diversity index value of 2.3 during the dry season was higher than that during the wet season (2.0), whereas the species richness index was higher during the wet season (3.4) than that during the dry season (2.9). The diversity and richness indices decreased towards the downstream direction from station 1 to station 3 during both seasons. In the present study, the species richness was significantly $(p$ value $\leq 0.05)$ and highly correlated with $\mathrm{pH}\left(R^{2}=+0.799\right)$ and DO $\left(R^{2}=+0.755\right)$ as shown in Table 3 . The highest values of $\mathrm{pH}(6.8)$ and $\mathrm{DO}(8.2 \mathrm{mg} / \mathrm{L})$ were observed at station 1 and were significantly higher $(p$ value $\leq 0.05)$ than those at other stations (Table 4 ). The water $\mathrm{pH}$ value dropped significantly to $5.8(p$ value $\leq 0.05)$ at station 2 which is located below the Murum Hydroelectric Powerhouse and continued to deteriorate at station 3 which is located further down at the transitional zone; but, the water $\mathrm{pH}$ value improved at stations 4 and 5 which are inundated. Deterioration of water quality, particularly water $\mathrm{pH}$ and $\mathrm{DO}$, is commonly observed in a river located downstream of a 
TABLe 1: The list of fish composition in the Murum River during the dry (trip 1) and wet (trip 2) seasons.

\begin{tabular}{|c|c|c|c|c|c|c|c|c|c|c|c|c|c|}
\hline \multirow{2}{*}{ Family } & \multirow{2}{*}{ Species } & \multicolumn{6}{|c|}{ Trip 1} & \multicolumn{6}{|c|}{ Trip 2} \\
\hline & & St1 & St2 & St3 & St4 & St5 & Murum River & St1 & St2 & St3 & St4 & St5 & Murum River \\
\hline \multirow{3}{*}{ Bagridae } & Hemibagrus fortis & 2 & - & 1 & - & - & 3 & - & - & - & - & - & - \\
\hline & Hemibagrus capitulum & 2 & - & 5 & 1 & 2 & 10 & 4 & - & 3 & 1 & 4 & 12 \\
\hline & Mystus singaringan & 4 & - & 1 & 3 & 7 & 15 & - & - & - & 1 & - & 1 \\
\hline Cobitidae & Syncrossus hymenophysa & - & - & - & - & - & - & - & - & - & 1 & - & 1 \\
\hline Cichlidae & Oreochromis mossambicus & - & - & - & 2 & 9 & 11 & - & 2 & 21 & - & 4 & 27 \\
\hline \multirow{16}{*}{ Cyprinidae } & Barbonymus schwanenfeldii & 11 & 4 & 4 & 11 & 46 & 76 & 10 & 2 & 16 & 57 & 33 & 118 \\
\hline & Cyclocheilichthys apogon & 24 & 1 & 44 & 2 & 5 & 76 & - & 7 & 13 & 4 & 5 & 29 \\
\hline & Cyclocheilichthys armatus & - & - & - & - & - & - & - & 1 & - & - & 1 & 2 \\
\hline & Hampala bimaculata & 4 & 4 & - & - & - & 8 & - & 1 & - & - & - & 1 \\
\hline & Hampala macrolepidota & 1 & - & 1 & 11 & 1 & 14 & 1 & - & 1 & 1 & 8 & 11 \\
\hline & Labiobarbus festivus & 2 & 1 & - & - & - & 3 & - & - & - & - & - & - \\
\hline & Lobocheilos ovalis & 4 & 1 & 8 & 4 & 8 & 25 & 5 & 1 & 2 & 1 & 1 & 10 \\
\hline & Lobocheilos cf. falcifier & - & - & - & - & - & - & - & - & 1 & 1 & 2 & 4 \\
\hline & Osteochilus borneensis & 1 & - & - & - & - & 1 & - & - & - & - & - & - \\
\hline & Osteochilus enneaporos & 11 & - & - & - & - & 11 & 7 & 1 & 1 & - & - & 9 \\
\hline & Osteochilus hasseltii & 44 & 1 & 2 & 3 & 4 & 54 & - & - & - & - & - & - \\
\hline & Osteochilus schlegelii & 1 & - & - & - & - & 1 & - & - & - & - & - & - \\
\hline & Parachela oxygastroides & 1 & - & - & 21 & 12 & 34 & 5 & 6 & 2 & 1 & 15 & 29 \\
\hline & Puntioplites waandersi & - & 2 & 2 & 4 & 7 & 15 & 1 & - & 1 & 2 & - & 4 \\
\hline & Rasbora argyrotaenia & - & - & - & - & - & - & 2 & 2 & - & - & - & 4 \\
\hline & Tor tambra & - & - & - & - & 1 & 1 & 1 & - & - & - & - & 1 \\
\hline Mastacembelidae & Mastacembelus erythrotaenia & - & - & - & - & - & - & - & - & - & - & 1 & 1 \\
\hline Pangasiidae & Pangasius macronema & - & - & - & - & - & - & 1 & - & - & - & - & 1 \\
\hline \multirow{4}{*}{ Siluridae } & Kryptopterus cryptopterus & - & - & - & - & - & - & - & - & - & 1 & - & 1 \\
\hline & Kryptopterus lais & - & - & - & - & - & - & 1 & - & - & - & - & 1 \\
\hline & Kryptopterus limpok & - & - & - & 2 & - & 2 & - & - & - & - & - & - \\
\hline & $N$ & 112 & 14 & 68 & 64 & 102 & 360 & 38 & 23 & 61 & 71 & 74 & 267 \\
\hline
\end{tabular}

$n=$ number of individuals; $\mathrm{St}=$ station.

TABLe 2: Fish biological indices in the Murum River during the dry (trip 1) and wet (trip 2) seasons.

\begin{tabular}{|c|c|c|c|c|c|c|}
\hline \multirow{2}{*}{ Station } & \multicolumn{2}{|c|}{ Species diversity $(H)$} & \multicolumn{2}{|c|}{ Species richness $(D)$} & \multicolumn{2}{|c|}{ Species evenness $(J)$} \\
\hline & Trip 1 & Trip 2 & Trip 1 & Trip 2 & Trip 1 & Trip 2 \\
\hline 1 & 1.9 & 2.1 & 2.8 & 2.7 & 0.7 & 0.9 \\
\hline 2 & 1.7 & 1.9 & 2.3 & 2.6 & 0.9 & 0.9 \\
\hline 3 & 1.3 & 1.7 & 1.9 & 2.2 & 0.6 & 0.7 \\
\hline 4 & 2.0 & 0.9 & 2.4 & 2.3 & 0.8 & 0.4 \\
\hline 5 & 1.8 & 1.7 & 2.2 & 2.1 & 0.8 & 0.7 \\
\hline Murum River & 2.3 & 2.0 & 2.9 & 3.4 & 0.8 & 0.7 \\
\hline
\end{tabular}

hydroelectric dam [2]. The modification of the physicochemical states of the habitat downstream of the powerhouse could remove certain species that are vulnerable to physicochemical fluctuations, thus the decrease in species richness. Abiotic parameters of water quality have been known to have great impacts on species richness [35]. The lowest fish abundance was also consistently observed at station 2 , which was located below the powerhouse (Table 1). The DO values at all stations located below the powerhouse were significantly lower $(p$ value $\leq 0.05)$ than station 1 (upstream of the powerhouse), ranging from $2.1 \mathrm{mg} / \mathrm{L}$ to $4.1 \mathrm{mg} / \mathrm{L}$ and from $2.7 \mathrm{mg} / \mathrm{L}$ to $4.2 \mathrm{mg} / \mathrm{L}$, during the dry and wet seasons, respectively (Table 4). The lowest DO value was also observed at stations 2 and 3 during the dry season but improved significantly ( $p$ value $\leq 0.05)$ during the wet season. The significant improvement in DO during the wet season at stations 2 and 3 might also be the reason for the higher species richness at those stations during the wet season. Noticeable changes in biological indices between dry and wet seasons were observed at stations 3 and 4, which were located at the transitional zone and the tributary of the Murum River, respectively. Station 3 had the lowest diversity, richness, and evenness indices during the dry season. These lowest biological indices coincided with the worst water quality indicated by the lowest $\mathrm{pH}$ (5.5) and DO $(2.1 \mathrm{mg} / \mathrm{L})$ values and the highest turbidity (60.5 NTU), the parameters of which were known for their detrimental effects on fishes [30-32]. However, during the wet season, the 
TABLE 3: Correlation between in situ water quality and fish biological indices at the Murum River.

\begin{tabular}{lcccccc}
\hline & Depth $(\mathrm{m})$ & $\mathrm{Temp}\left({ }^{\circ} \mathrm{C}\right)$ & $\mathrm{pH}$ & $\mathrm{DO}(\mathrm{mg} / \mathrm{L})$ & Cond $(\mu \mathrm{S} / \mathrm{cm})$ & Turbidity $(\mathrm{NTU})$ \\
\hline Diversity & -0.395 & -0.032 & +0.405 & +0.401 & -0.330 & -0.089 \\
Richness & -0.450 & -0.059 & $+0.799^{* *}$ & $+0.755^{*}$ & -0.413 & -0.330 \\
Evenness & -0.479 & -0.379 & +0.147 & +0.058 & -0.009 & +0.097 \\
\hline
\end{tabular}

${ }^{*} p$ value $\leq 0.05$.

TABle 4: In situ water quality of the Murum River during the dry (trip 1) and wet seasons (trip 2).

\begin{tabular}{|c|c|c|c|c|c|c|}
\hline \multirow{2}{*}{ Parameter } & \multirow{2}{*}{ Sampling } & \multicolumn{5}{|c|}{ Station } \\
\hline & & 1 & 2 & 3 & 4 & 5 \\
\hline \multirow{2}{*}{ Depth (m) } & Trip 1 & $4.1 \pm 0.3^{a 1}$ & $6.6 \pm 0.2^{b 1}$ & $12.6 \pm 0.1^{c 2}$ & $28.1 \pm 0.1^{e 2}$ & $23.3 \pm 0.1^{d 2}$ \\
\hline & Trip 2 & $5.2 \pm 0.1^{a 2}$ & $6.7 \pm 0.1^{b 1}$ & $10.8 \pm 0.1^{c 1}$ & $27.2 \pm 0.2^{e 1}$ & $19.4 \pm 0.1^{d 1}$ \\
\hline \multirow{2}{*}{$\operatorname{Temp}\left({ }^{\circ} \mathrm{C}\right)$} & Trip 1 & $28.7 \pm 0.0^{b 2}$ & $25.0 \pm 0.1^{a 1}$ & $25.5 \pm 0.0^{a 1}$ & $29.6 \pm 0.1^{c 1}$ & $30.2 \pm 0.5^{c 1}$ \\
\hline & Trip 2 & $27.7 \pm 0.0^{b 1}$ & $24.9 \pm 0.0^{a 1}$ & $28.6 \pm 0.4^{c 2}$ & $29.6 \pm 0.2^{d 1}$ & $30.3 \pm 0.3^{d 1}$ \\
\hline \multirow{2}{*}{$\mathrm{pH}$} & Trip 1 & $6.8 \pm 0.0^{e 2}$ & $5.7 \pm 0.0^{b 1}$ & $5.5 \pm 0.0^{a 1}$ & $5.8 \pm 0.0^{c 1}$ & $6.0 \pm 0.0^{d 1}$ \\
\hline & Trip 2 & $6.7 \pm 0.0^{d 1}$ & $5.9 \pm 0.0^{b 2}$ & $5.6 \pm 0.0^{a 2}$ & $6.0 \pm 0.0^{c 2}$ & $6.0 \pm 0.0^{c 1}$ \\
\hline \multirow{2}{*}{$\mathrm{DO}(\mathrm{mg} / \mathrm{L})$} & Trip 1 & $8.2 \pm 0.0^{d 1}$ & $2.1 \pm 0.0^{a 1}$ & $2.1 \pm 0.0^{a 1}$ & $4.1 \pm 0.1^{c 1}$ & $3.3 \pm 3.0^{b 1}$ \\
\hline & Trip 2 & $8.2 \pm 0.0^{d 1}$ & $2.8 \pm 0.0^{a 2}$ & $4.2 \pm 0.1^{c 2}$ & $4.2 \pm 0.3^{c 1}$ & $3.5 \pm 2.7^{b 1}$ \\
\hline \multirow{2}{*}{ Cond $(\mu \mathrm{S} / \mathrm{cm})$} & Trip 1 & $33.8 \pm 0.0^{a 2}$ & $53.2 \pm 0.5^{e 2}$ & $46.3 \pm 0.0^{c 2}$ & $49.4 \pm 0.0^{d 2}$ & $44.6 \pm 0.4^{b 2}$ \\
\hline & Trip 2 & $28.4 \pm 0.0^{a 1}$ & $46.8 \pm 0.1^{d 1}$ & $37.5 \pm 0.3^{b 1}$ & $45.5 \pm 0.6^{c 1}$ & $37.1 \pm 0.2^{b 1}$ \\
\hline \multirow{2}{*}{ Turbidity (NTU) } & Trip 1 & $10.4 \pm 0.1^{a 2}$ & $44.6 \pm 0.6^{b 2}$ & $60.5 \pm 0.2^{c 2}$ & $57.0 \pm 3.6^{c 2}$ & $8.3 \pm 1.0^{a 1}$ \\
\hline & Trip 2 & $6.6 \pm 0.0^{a 1}$ & $36.1 \pm 0.4^{d 1}$ & $20.5 \pm 2.0^{c 1}$ & $14.6 \pm 1.8^{b 1}$ & $7.8 \pm 2.0^{a 1}$ \\
\hline
\end{tabular}

The mean followed by the same letter in the same row indicates no significant difference between stations, whereas the mean followed by the same number at each station for each parameter indicates no significant difference between trips ( $p$ value $>0.05$ ).

biological indices at station 3 improved when these water quality parameters improved significantly $(p$ value $\leq 0.05)$ (Table 4). On the contrary, the diversity and evenness indices at station 4 during the wet season were the lowest among stations and lower than those during the dry season as well, although species richness remained similar during both seasons. Unlike station 3, the diversity and evenness indices at station 4 decreased remarkably even though $\mathrm{pH}$ and turbidity improved significantly $(p$ value $\leq 0.05)$ during the wet season (Table 4 ). This phenomenon demonstrated that the fish assemblage at the inundated tributary station was less influenced by the water quality parameters than the transitional zone at the main river. Instead, the low diversity and evenness index at station 4 during the wet season are most probably due to the migration of the fish to the upstream of Sungai Temaju where station 4 is located during the onset of the rainy season, and thus the dominance of Barbonymus schwanenfeldii which has demonstrated upriver breeding migratory behaviour [36].

The river depth in the present study increased significantly ( $p$ value $\leq 0.05$ ) from station 1 at upstream $(4.7 \mathrm{~m})$ to station $4(27.7 \mathrm{~m})$ and station $5(21.4 \mathrm{~m})$ at the inundated area (Table 4). Depth is one of the important habitat variables in determining fish distribution in a river, yet river depth in the present study was not significantly correlated with fish biological indices ( $p$ value $>0.05$ ). Nyanti [5] found that fish species diversity was significantly and positively correlated with the mean depth of a river located downstream of the Batang Ai Dam. The author demonstrated that the fish assemblage in a shallow river in the upstream segment is less diverse than a deeper river in the middle stream and downstream segments. The lack of correlation between river depth and fish biological indices in the present study might be due to very deep water at the downstream stations as they were located in the inundated area of the Bakun Dam reservoir.

3.2. Length-Weight Relationship and Condition Factor. Table 5 shows the length-weight relationship (LWR) for selected fish species with the coefficient of determination $\left(R^{2}\right)$ greater than 0.80 in the Murum River. The results indicated that the growth patterns of five fish species including Barbonymus schwanenfeldii, Cyclocheilichthys apogon, Hampala macrolepidota, Lobocheilos ovalis, and Osteochilus enneaporos were better during the wet season than those during the dry season. This could be due to the rising of the water level during the wet season which inundated the larger area and thus increasing food supplies to the fish [34]. The growth patterns of the three fish species were the same during both seasons where Parachela oxygastroides and Hemibagrus capitulum showed positive allometric growth, while Oreochromis mossambicus showed negative allometric growth for both seasons. The LWR for Mystus singaringan, Osteochilus hasseltii, and Puntioplites waandersi was determined at the dry season only due to the low number of individuals caught during the wet season. $O$. hasseltii exhibited isometric growth $(b=3.007)$, while $M$. singaringan $(b=3.555)$ and $P$. waandersi $(b=3.162)$ exhibited positive allometric growth.

The condition factor $(K)$ for all selected species ranged from 0.61 to 2.04 and from 0.62 to 2.19 during the dry and 
TABLE 5: Summary of regression analyses of the length-weight relationship (LWR) of selected species in the Murum River during the dry (trip 1) and wet (trip 2) seasons.

\begin{tabular}{|c|c|c|c|c|c|c|c|c|c|c|c|}
\hline \multirow[t]{2}{*}{ Family } & \multirow[t]{2}{*}{ Species } & \multirow[t]{2}{*}{ Trip } & \multicolumn{3}{|c|}{$\begin{array}{c}\log \mathrm{BW}=\log a+b \\
\log \mathrm{TL}\end{array}$} & \multirow{2}{*}{\multicolumn{2}{|c|}{$\begin{array}{l}\text { Parameter } \\
\text { estimates }\end{array}$}} & \multirow[t]{2}{*}{ SE } & \multirow{2}{*}{$\begin{array}{c}p \\
\text { value }\end{array}$} & \multirow[t]{2}{*}{ LWR: $W=a \mathrm{~L}^{b}$} & \multirow[t]{2}{*}{$\begin{array}{l}\text { Growth } \\
\text { pattern }\end{array}$} \\
\hline & & & $n$ & $R^{2}$ & $p$ value & & & & & & \\
\hline \multirow{4}{*}{ Barigdae } & \multirow[t]{2}{*}{ Mystus singaringan } & 1 & 12 & 0.805 & 0.001 & $\begin{array}{c}\log a \\
b\end{array}$ & $\begin{array}{c}-6.857 \\
3.555\end{array}$ & $\begin{array}{l}1.748 \\
0.553\end{array}$ & $\begin{array}{l}0.003 \\
0.001\end{array}$ & $W=0.0011 \mathrm{~L}^{3.555}$ & $A+$ \\
\hline & & 2 & NA & & & & & & & & \\
\hline & \multirow[b]{2}{*}{ Hemibagrus capitulum } & 1 & 10 & 0.955 & 0.001 & $\log a$ & -5.333 & 0.843 & 0.001 & $W=0.0048 \mathrm{~L}^{3.129}$ & $\mathrm{~A}+$ \\
\hline & & 2 & 12 & 0.983 & 0.001 & $\begin{array}{c}b \\
\log a \\
b\end{array}$ & $\begin{array}{c}3.129 \\
-6.473 \\
3.457\end{array}$ & $\begin{array}{l}0.240 \\
0.491 \\
0.143\end{array}$ & $\begin{array}{l}0.001 \\
0.001 \\
0.001\end{array}$ & $W=0.0015 \mathrm{~L}^{3.457}$ & $A+$ \\
\hline \multirow{2}{*}{ Cichlidae } & \multirow{2}{*}{ Oreochromis mossambicus } & 1 & 11 & 0.961 & 0.001 & $\underset{b}{\log a}$ & $\begin{array}{l}-3.170 \\
2.744\end{array}$ & $\begin{array}{l}0.525 \\
0.185\end{array}$ & $\begin{array}{l}0.001 \\
0.001\end{array}$ & $W=0.0420 \mathrm{~L}^{2.744}$ & $A-$ \\
\hline & & 2 & 13 & 0.948 & 0.001 & $\begin{array}{c}\log a \\
b\end{array}$ & $\begin{array}{c}-2.545 \\
2.562\end{array}$ & $\begin{array}{l}0.531 \\
0.181\end{array}$ & $\begin{array}{l}0.001 \\
0.001\end{array}$ & $W=0.0785 \mathrm{~L}^{2.562}$ & $A-$ \\
\hline \multirow{16}{*}{ Cyprinidae } & \multirow{2}{*}{$\begin{array}{l}\text { Barbonymus } \\
\text { schwanenfeldii }\end{array}$} & 1 & 72 & 0.899 & 0.001 & $\begin{array}{l}\log a \\
b\end{array}$ & $\begin{array}{c}-3.571 \\
2.686\end{array}$ & $\begin{array}{l}0.314 \\
0.108\end{array}$ & $\begin{array}{l}0.001 \\
0.001\end{array}$ & $W=0.0281 \mathrm{~L}^{2.686}$ & $A-$ \\
\hline & & 2 & 118 & 0.947 & 0.001 & $\underset{b}{\log a}$ & $\begin{array}{c}-4.496 \\
3.004\end{array}$ & $\begin{array}{l}0.181 \\
0.066\end{array}$ & $\begin{array}{l}0.001 \\
0.001\end{array}$ & $W=0.0112 \mathrm{~L}^{3.004}$ & I \\
\hline & \multirow[b]{2}{*}{ Cyclocheilichthys apogon } & 1 & 74 & 0.920 & 0.001 & $\begin{array}{l}\log a \\
b\end{array}$ & $\begin{array}{c}-4.610 \\
3.048\end{array}$ & $\begin{array}{l}0.290 \\
0.106\end{array}$ & $\begin{array}{l}0.001 \\
0.001\end{array}$ & $W=0.0100 \mathrm{~L}^{3.048}$ & I \\
\hline & & 2 & 29 & 0.972 & 0.001 & $\log a$ & $\begin{array}{c}-6.043 \\
3.614\end{array}$ & $\begin{array}{l}0.305 \\
0.117\end{array}$ & $\begin{array}{l}0.001 \\
0.001\end{array}$ & $W=0.0024 \mathrm{~L}^{3.614}$ & $\mathrm{~A}+$ \\
\hline & \multirow[b]{2}{*}{ Hampala macrolepidota } & 1 & 12 & 0.874 & 0.001 & $\underset{b}{\log a}$ & $\begin{array}{c}-3.056 \\
2.481\end{array}$ & $\begin{array}{l}0.895 \\
0.298\end{array}$ & $\begin{array}{l}0.007 \\
0.001\end{array}$ & $W=0.0471 \mathrm{~L}^{2.481}$ & A- \\
\hline & & 2 & 11 & 0.994 & 0.001 & $\underset{b}{\log a}$ & $\begin{array}{c}-5.136 \\
3.192\end{array}$ & $\begin{array}{l}0.240 \\
0.085\end{array}$ & $\begin{array}{l}0.001 \\
0.001\end{array}$ & $W=0.0059 \mathrm{~L}^{3.192}$ & $A+$ \\
\hline & \multirow{2}{*}{ Lobocheilos ovalis } & 1 & 24 & 0.893 & 0.001 & $\begin{array}{l}\log a \\
b\end{array}$ & $\begin{array}{c}-4.558 \\
2.933\end{array}$ & $\begin{array}{l}0.653 \\
0.216\end{array}$ & $\begin{array}{l}0.001 \\
0.001\end{array}$ & $W=0.0105 \mathrm{~L}^{2.933}$ & A- \\
\hline & & 2 & 6 & 0.848 & 0.009 & $\log _{b} a$ & $\begin{array}{l}-11.665 \\
5.408\end{array}$ & $\begin{array}{l}3.380 \\
1.145\end{array}$ & $\begin{array}{l}0.026 \\
0.009\end{array}$ & $W=0.0000 \mathrm{~L}^{5.408}$ & $\mathrm{~A}+$ \\
\hline & \multirow{2}{*}{ Osteochilus enneaporos } & 1 & 11 & 0.882 & 0.001 & $\underset{b}{\log a}$ & $\begin{array}{c}-4.355 \\
2.900\end{array}$ & $\begin{array}{l}1.049 \\
0.354\end{array}$ & $\begin{array}{l}0.002 \\
0.001\end{array}$ & $W=0.0128 \mathrm{~L}^{2.900}$ & $A-$ \\
\hline & & 2 & 9 & 0.922 & 0.001 & $\underset{b}{\log a}$ & $\begin{array}{c}-5.969 \\
3.436\end{array}$ & $\begin{array}{l}1.155 \\
0.378\end{array}$ & $\begin{array}{l}0.001 \\
0.001\end{array}$ & $W=0.0026 \mathrm{~L}^{3.436}$ & $\mathrm{~A}+$ \\
\hline & \multirow[t]{2}{*}{ Osteochilus hasseltii } & 1 & 53 & 0.869 & 0.001 & $\underset{b}{\log a}$ & $\begin{array}{c}-4.650 \\
3.007\end{array}$ & $\begin{array}{l}0.481 \\
0.163\end{array}$ & $\begin{array}{l}0.001 \\
0.001\end{array}$ & $W=0.0096 \mathrm{~L}^{3.007}$ & I \\
\hline & & 2 & NA & & & & & & & & \\
\hline & \multirow{2}{*}{ Parachela oxygastroides } & 1 & 27 & 0.814 & 0.001 & $\begin{array}{l}\log a \\
b\end{array}$ & $\begin{array}{c}-5.916 \\
3.306\end{array}$ & $\begin{array}{l}0.914 \\
0.316\end{array}$ & $\begin{array}{l}0.001 \\
0.001\end{array}$ & $W=0.0027 \mathrm{~L}^{3.306}$ & $\mathrm{~A}+$ \\
\hline & & 2 & 24 & 0.831 & 0.001 & $\log _{b} a$ & $\begin{array}{c}-6.706 \\
3.571\end{array}$ & $\begin{array}{l}0.870 \\
0.310\end{array}$ & $\begin{array}{l}0.001 \\
0.001\end{array}$ & $W=0.0012 \mathrm{~L}^{3.571}$ & $\mathrm{~A}+$ \\
\hline & \multirow{2}{*}{ Puntioplites waandersi } & 1 & 14 & 0.986 & 0.001 & $\underset{b}{\log a}$ & $\begin{array}{c}-5.006 \\
3.162\end{array}$ & $\begin{array}{l}0.360 \\
0.110\end{array}$ & $\begin{array}{l}0.001 \\
0.001\end{array}$ & $W=0.0067 \mathrm{~L}^{3.162}$ & $\mathrm{~A}+$ \\
\hline & & 2 & NA & & & & & & & & \\
\hline
\end{tabular}

$n$, number of individuals; $R^{2}$, coefficient of determination; SE, standard error; SD, standard deviation; A+, positive allometry; A-, negative allometry; I, isometric. Significant values $(p$ value $<0.05)$ are indicated in bold.

wet seasons, respectively (Table 6). There are no noticeable changes in fish condition factor in the two different seasons except for $L$. ovalis where the condition factor of fish was better during the wet season. Almost half of the selected species in the Murum River scored a $K$ value of less than 1.0, signifying poor fish condition and unsuitable environment for fish growth [37]. The exotic species $O$. mossambicus had the highest $K$ value $(>2)$ in the present study, indicating that fish is in excellent condition and thriving better in the Murum River compared to the Malaysian native species. This serves as a warning sign of the potential biological intrusion and threat to the native species.
The growth patterns of fish in the present study were dissimilar compared to those in the downstream river of the Batang Ai Dam where Nyanti [5] reported that C. apogon exhibited negative allometric growth, whereas $H$. macrolepidota and $H$. capitulum exhibited isometric growth. The author also showed that the condition factor value gradually decreased from the most abundant species C. apogon to the third most abundant species $H$. capitulum at the downstream river of the Batang Ai Dam [5] which is similar with the present study where the $K$ value of $C$. apogon was the highest among the three species, followed by $H$. macrolepidota and $H$. capitulum. Nevertheless, the 
TABle 6: The condition factor $(K)$ of the selected species in the Murum River during dry (trip 1) and wet (trip 2) seasons.

\begin{tabular}{|c|c|c|c|c|c|}
\hline \multirow{2}{*}{ Family } & \multirow{2}{*}{ Species } & \multicolumn{2}{|c|}{ Trip 1} & \multicolumn{2}{|c|}{ Trip 2} \\
\hline & & $n$ & $K \pm \mathrm{SD}$ & $n$ & $\mathrm{~K} \pm \mathrm{SD}$ \\
\hline \multirow{2}{*}{ Bagridae } & Mystus singaringan & 12 & $0.61 \pm 0.09$ & - & - \\
\hline & Hemibagrus capitulum & 10 & $0.78 \pm 0.18$ & 12 & $0.76 \pm 0.17$ \\
\hline Cichlidae & Oreochromis mossambicus & 11 & $2.04 \pm 0.15$ & 13 & $2.19 \pm 0.31$ \\
\hline \multirow{8}{*}{ Cyprinidae } & Barbonymus schwanenfeldii & 72 & $1.14 \pm 0.22$ & 118 & $1.16 \pm 0.34$ \\
\hline & Cyclocheilichthys apogon & 74 & $1.14 \pm 0.09$ & 29 & $1.18 \pm 0.20$ \\
\hline & Hampala macrolepidota & 12 & $1.01 \pm 0.16$ & 11 & $1.01 \pm 0.15$ \\
\hline & Lobocheilos ovalis & 24 & $0.86 \pm 0.08$ & 6 & $1.06 \pm 0.19$ \\
\hline & Osteochilus enneaporos & 11 & $0.96 \pm 0.11$ & 9 & $0.97 \pm 0.09$ \\
\hline & Osteochilus hasseltii & 53 & $0.99 \pm 0.14$ & - & - \\
\hline & Parachela oxygastroides & 27 & $0.65 \pm 0.05$ & 24 & $0.62 \pm 0.13$ \\
\hline & Puntioplites waandersi & 14 & $1.14 \pm 0.14$ & - & - \\
\hline
\end{tabular}

$n$, number of individuals; $K$, condition factor; $\mathrm{SD}$, standard deviation.

TABLE 7: The stomach content analysis of four selected species by using the frequency occurrence of food and mass method.

\begin{tabular}{|c|c|c|c|c|}
\hline Species & $n$ & Type of food item & Frequency of occurrence (\%) & Mass method (\%) \\
\hline \multirow{5}{*}{ Barbonymus schwanenfeldii } & \multirow{5}{*}{53} & Insect & 92.5 & 15.7 \\
\hline & & Oligochaetes & 26.4 & 0.1 \\
\hline & & Seeds & 24.5 & 1.5 \\
\hline & & Plant parts & 24.5 & 8.5 \\
\hline & & Detritus & 100.0 & 74.2 \\
\hline \multirow{4}{*}{ Cyclocheilichthys apogon } & \multirow{4}{*}{27} & Insect & 66.7 & 4.3 \\
\hline & & Oligochaetes & 3.7 & 0.1 \\
\hline & & Plant parts & 14.8 & 0.6 \\
\hline & & Detritus & 92.6 & 95.0 \\
\hline \multirow{3}{*}{ Parachela oxygastroides } & \multirow{3}{*}{40} & Insect & 87.5 & 20.3 \\
\hline & & Plant parts & 5.0 & 0.2 \\
\hline & & Detritus & 100.0 & 79.5 \\
\hline \multirow{3}{*}{ Hampala macrolepidota } & \multirow{3}{*}{13} & Crustaceans & 92.3 & 9.4 \\
\hline & & Plant parts & 7.7 & 0.1 \\
\hline & & Detritus & 100.0 & 90.5 \\
\hline
\end{tabular}

condition factors of these fish species were higher at the downstream river of the Batang Ai Dam compared to the present study, likely due to being in a regulated lotic environment compared to the lentic environment.

3.3. Stomach Content Analysis. Table 7 shows the stomach content of Barbonymus schwanenfeldii, Cyclocheilichthys apogon, Parachela oxygastroides, and Hampala macrolepidota by using the frequency of occurrence (FO) and mass method (MM). The stomach content of B. schwanenfeldii $(n=53)$ comprised insects, oligochaetes, seeds, plant parts, and detritus. The highest FO of food in B. schwanenfeldii was detritus (100.0\%), followed by insects (92.5\%), oligochaetes (26.4\%), seeds $(24.5 \%)$, and plant parts $(24.5 \%)$. In \% mass, detritus contributed $74.2 \%$ of the total mass of stomach content, followed by insects $(15.7 \%)$, plant parts $(8.5 \%)$, seeds $(1.5 \%)$, and oligochaetes $(0.1 \%)$. The diet composition of C. apogon $(n=27)$ comprised insects, oligochaetes, plant parts, and detritus. Detritus had the highest FO (92.6\%), followed by insects (66.7\%), plant parts (14.8\%), and oligochaetes (3.7\%). Detritus also had the highest \% mass with
95.0\% of the total mass of C. apogon stomach content, followed by insects $(4.3 \%)$, plant parts $(0.6 \%)$, and oligochaetes $(0.1 \%)$. The stomach content of $P$. oxygastroides $(n=40)$ comprised insects, plant parts, and detritus with a FO of $87.5 \%, 5.0 \%$, and $100.0 \%$, respectively. Mass method showed that the stomach content of $P$. oxygastroides was also highly composed of detritus which was $79.5 \%$ of the total mass of stomach content, followed by insects $(20.3 \%)$ and then plant parts with only $0.2 \%$ of the total mass of stomach content. The FO of detritus (100.0\%) and crustaceans (92.3\%) was high, while the FO of plant parts was low $(7.7 \%)$ in H. macrolepidota $(n=13)$. In $\%$ mass, detritus, crustaceans, and plant parts contributed $90.5 \%, 9.4 \%$, and $0.1 \%$ of the total mass of stomach content, respectively.

Among the selected species, $B$. schwanenfeldii had the most diverse food items observed during the analyses, indicating a wider feeding habit which contributes to its higher distribution and abundance in the Murum River. Hamid et al. [38] described C. apogon as omnivorous and found that the stomach content of C. apogon mainly consisted of Oligochaeta, Chironomidae, and detritus. The finding was consistent with the type of food found in C. apogon in the 
present study. Makmur et al. [39] documented that $H$. macrolepidota is a carnivorous fish species, which is in agreement with the present study where the stomach content of fish was high in crustaceans $(\mathrm{FO}>90 \%)$. Nevertheless, plant parts were also found in the stomach contents of $P$. oxygastroides and $H$. macrolepidota, although the FO $(\approx 6.4 \%)$ and $\mathrm{MM}(\approx 0.2 \%)$ were low. This shows that these fish species can modify their diet by feeding on plant materials during the limitation of preferred food [40].

\section{Conclusions}

The present study showed that cascade dams influenced the fish assemblage and biological indices in the Murum River that is located between the two cascading dams of Bakun and Murum. The Murum Hydroelectric Powerhouse had exerted a major influence on the fish abundance, species diversity, and richness due to the deterioration of water quality, particularly water $\mathrm{pH}$ and DO. The most profound impact on species diversity, richness, and evenness was observed at the transitional zone of the Bakun reservoir, particularly during the dry season. The family Cyprinidae was the most dominant family during the dry and wet seasons, while the abundant species varied between seasons, which is attributable to the migration behaviour of fish during the onset of the rainy season and ongoing restructuring of fish communities as the river has just been recently modified. The present study also demonstrated a potential threat of biological invasion on native species in the river as indicated by the increase of fish abundance coupled with the high condition factor of the exotic species, Oreochromis mossambicus. All native fish species in the river were in poor to fair condition, although some of the species exhibited better growth patterns during the wet season. Therefore, continuous and long-term monitoring of fish fauna is necessary to better understand the fish composition and distribution patterns in the newly modified river to improve long-term forecasts and to develop invasion species management plan for conservation of the native species in the river.

\section{Data Availability}

The data used to support the findings of this study are available from the corresponding author upon request.

\section{Conflicts of Interest}

The authors declare that there are no conflicts of interest regarding the publication of this paper.

\section{Acknowledgments}

The authors appreciate the facilities provided by Universiti Malaysia Sarawak during the research and the publication fee supported by Universiti Malaysia Sabah. This research was funded by Sarawak Energy Berhad (GL (F07)/SEB/5A/ 2013(28)).

\section{References}

[1] Q. Zhao, S. Liu, L. Deng et al., "Landscape change and hydrologic alteration associated with dam construction," International Journal of Applied Earth Observation and Geoinformation, vol. 16, no. 1, pp. 17-26, 2012.

[2] T. Y. Ling, C. L. Soo, T. L. E. Heng, L. Nyanti, S. F. Sim, and J. Grinang, "Physicochemical characteristics of river water downstream of a large tropical hydroelectric dam," Journal of Chemistry, vol. 2016, Article ID 7895234, 7 pages, 2016.

[3] T. Y. Ling, N. Gerunsin, C. L. Soo, L. Nyanti, S. F. Sim, and J. Grinang, "Seasonal changes and spatial variation in water quality of a large young tropical reservoir and its downstream river," Journal of Chemistry, vol. 2017, Article ID 8153246, 16 pages, 2017.

[4] R. V. Granzotti, L. E. Miranda, A. A. Agostinho, and L. C. Gomes, "Downstream impacts of dams: shifts in benthic invertivorous fish assemblages," Aquatic Sciences, vol. 80, no. 3, pp. 1-14, 2018.

[5] L. Nyanti, N. I. Noor-Azhar, C. L. Soo et al., "Physicochemical parameters and fish assemblages in the downstream river of a tropical hydroelectric dam subjected to diurnal changes in flow," International Journal of Ecology, vol. 20189 pages, Article ID 8690948, 2018.

[6] J. Li, H. Zhang, D. Lin et al., "Spatiotemporal distribution and assemblages of fishes below the lowermost dam in protected reach in the yangtze river main stream: implications for river management," BioMed Research International, vol. 2016, Article ID 4290793, 8 pages, 2016.

[7] J. Li, S. Dong, S. Liu, Z. Yang, M. Peng, and C. Zhao, "Effects of cascading hydropower dams on the composition, biomass and biological integrity of phytoplankton assemblages in the middle lancang-mekong river," Ecological Engineering, vol. 60, pp. 316-324, 2013.

[8] Q. Liu, S. Liu, H. Zhao et al., "Longitudinal variability of phosphorus fractions in sediments of a canyon reservoir due to cascade dam construction: a case study in Lancang river, China," PLoS One, vol. 8, no. 12, 2013.

[9] J. Y. Xie, W. J. Tang, and Y. H. Yang, "Fish assemblage changes over half a century in the yellow river, China," Ecology and Evolution, vol. 8, no. 8, pp. 4173-4182, 2018.

[10] B. K. Sovacool and L. C. Bulan, "Energy security and hydropower development in Malaysia: the drivers and challenges facing the sarawak corridor of renewable energy (SCORE)," Renewable Energy, vol. 40, no. 1, pp. 113-129, 2012.

[11] R. F. Inger and P. K. Chin, Freshwater Fish of North Borneo, Natural History Publications, Kota Kinabalu, Malaysia, 2002.

[12] M. Kottelat, A. J. Whitten, S. N. Kartikasari, and S. Wirjoatmodjo, Freshwater Fishes of Western Indonesia and Sulawesi, Periplus Editions, Hong Kong, China, 1993.

[13] M. Kottelat, A. Pinder, and A. Harrison, "Tor tambra: the IUCN red list of threatened species 2018," 2018.

[14] M. Kottelat and H. H. Tan, "A synopsis of the genus Lobocheilos in Java, Sumatra and Borneo, with descriptions of six new species (Teleostei: Cyprinidae)," Ichthyological Exploration of Freshwaters, vol. 19, no. 1, pp. 27-58, 2008.

[15] M. Kottelat, "The fishes of the inland waters of Southeast Asia: a catalogue and core bibliography of the fishes known to occur in freshwaters, mangroves and estuaries," The Raffles Bulletin of Zoology, vol. 27, pp. 1-663, 2013.

[16] R. Froese and D. Pauly, "Fishbase: world wide web electronic publication," 2019. 
[17] R. Van Der Laan, R. Fricke, and W. N. Eschmeyer, "Eschmeyer's catalog of fishes classification," 2020.

[18] C. E. Shannon and W. Weaver, The Mathematical Theory of Communication, The University of Illinois Press, Urbana, IL, USA, 1964.

[19] E. C. Pielou, "Species-diversity and pattern-diversity in the study of ecological succession," Journal of Theoretical Biology, vol. 10, no. 2, pp. 370-383, 1966.

[20] R. Margalef, Perspectives in Ecological Theory, University of Chicago Press, Chicago, IL, USA, 1968.

[21] H. B. N. Hynes, "The food of fresh-water sticklebacks (Gasterosteus aculeatus and Pygosteus pungitius), with a review of methods used in studies of the food of fishes," The Journal of Animal Ecology, vol. 19, no. 1, pp. 36-58, 1950.

[22] E. D. Le Cren, "The length-weight relationship and seasonal cycle in gonad weight and condition in the perch (Perca fluviatilis)," Journal of Animal Ecology, vol. 20, no. 2, pp. 201-219, 1951.

[23] D. Pauly, Some Simple Methods for the Assessment of Tropical Fish Stocks, FAO, Rome, Italy, 1983.

[24] A. Sapis, G. T. Noweg, L. Nyanti, and J. Grinang, "Effects of land use on fish assemblages in inundated area of pleiran river and danum river sections of murum reservoir, Belaga, Sarawak: Malaysian," Annals of Applied Biology, vol. 47, no. 1, pp. 223-230, 2018.

[25] F. W. H. Beamish, P. Sa-Ardrit, and S. Tongnunui, "Habitat characteristics of the Cyprinidae in small rivers in central Thailand," Environmental Biology of Fishes, vol. 76, no. 2-4, pp. 237-253, 2006.

[26] Z. A. Muchlisin and M. N. Siti Azizah, "Diversity and distribution of freshwater fishes in aceh water, northern Sumatra, Indonesia," International Journal of Zoological Research, vol. 5, no. 2, pp. 67-79, 2009.

[27] T. D. Hau and T. T. Thuy, "Fish diversity and fishery status in the Ba Che and Tien Yen Rivers, northern Vietnam, with consideration on factors causing recent decline of fishery products," Kuroshio, vol. 7, no. 2, pp. 113-122, 2014.

[28] Z. A. Rashid, M. Asmuni, and M. N. A. Amal, "Fish diversity of tembeling and pahang rivers, Pahang, Malaysia," Check List, vol. 11, no. 5, pp. 1-6, 2015.

[29] F. A. Farinordin, N. N. Nazri, A. Samat et al., "Freshwater fishes of sungai sat and sungai kelapah, taman negara national park, Pahang," Journal Of Wildlife And Parks, vol. 31, pp. 49-60, 2016.

[30] L. Nyanti, C. L. Soo, M. S. Danial-Nakhaie et al., "Effects of water temperature and $\mathrm{pH}$ on total suspended solids tolerance of malaysian native and exotic fish species," AACL Bioflux, vol. 11, no. 3, 2018.

[31] L. Nyanti, N. N. K. Abu-Rashid, T. Y. Ling, C. L. Soo, S. F. Sim, and J. Grinang, "“Acidification tolerance of Barbonymus schwanenfeldii (Bleeker, 1854) and Oreochromis niloticus (Linnaeus, 1758)-implication of fish size," AACL Bioflux, vol. 10, no. 4, pp. 746-753, 2017.

[32] L. Nyanti, C. L. Soo, N. N. Ahmad-Tarmizi et al., "Effects of water temperature, dissolved oxygen and total suspended solids on juvenile Barbonymus schwanenfeldii (Bleeker, 1854) and Oreochromis niloticus (Linnaeus, 1758)," AACL Bioflux, vol. 11, no. 2, 2018.

[33] D. Simberloff, J.-L. Martin, P. Genovesi et al., "Impacts of biological invasions: what's what and the way forward," Trends in Ecology \& Evolution, vol. 28, no. 1, pp. 58-66, 2013.

[34] Z. Mohd Shafiq, M. S. Amir Shah Ruddin, H. H. Zarul, P. Khaled, M. Syaiful, and W. O. Wan Maznah, "The effect of seasonal changes on freshwater fish assemblages and environmental factors in bukit merah reservoir (Malaysia)," Transylvanian Review of Systematical and Ecological Research, vol. 16, no. 1, pp. 97-108, 2015.

[35] S. Tongnunui, F. W. H. Beamish, and C. Kongchaiya, "Fish species, relative abundances and environmental associations in small rivers of the mae klong river basin in Thailand," Agriculture and Natural Resources, vol. 50, no. 5, pp. 408-415, 2016.

[36] M. M. Isa, A. S. Md-Shah, S. A. Mohd-Sah, N. Baharudin, and M. A. Abdul-Halim, "Population dynamics of tinfoil barb, Barbonymus schwanenfeldii (Bleeker, 1853) in pedu reservoir, Kedah," Journal of Biology, Agriculture and Healthcare, vol. 2, no. 5, pp. 55-69, 2012.

[37] C. Barnham and A. Baxter, "Condition factor, k, for salmonid fish fish notes," 1998.

[38] M. Hamid, S. Bagheri, S. Nor, and M. Mansor, "A comparative study of seasonal food and feeding habits of beardless barb, Cyclocheilichthys apogon (Valenciennes, 1842), in temengor and bersia reservoirs, Malaysia, Iran," Journal of Fisheries Science, vol. 14, no. 4, pp. 1018-1028, 2015.

[39] S. Makmur, D. Arfiati, G. Bintoro, and A. W. Ekawati, "Food habit of hampala (Hampala macrolepidota Kuhl \& Van Hasselt 1823) and its position in food web, food pyramid and population equilibrium of ranau lake, Indonesia," Journal of Biodiversity and Environmental Sciences, vol. 4, no. 6, pp. 167-177, 2014.

[40] B. De Mérona and R. Vigouroux, "Diet changes in fish species from a large reservoir in south America and their impact on the trophic structure of fish assemblages (Petit-Saut Dam, French Guiana)," Annales de Limnologie-International Journal of Limnology, vol. 42, no. 1, pp. 53-61, 2006. 